\title{
Gelation of commercial pea protein isolate: effect of microbial transglutaminase and thermal processing
}

\author{
Helena María MORENO ${ }^{1,2 *}$ (D), Clara Asunción TOVAR³, Fátima DOMÍNGUEZ-TIMÓN, Jorge CANO-BÁEZ1, \\ María Teresa DÍAZ ${ }^{4}$, Mercedes Martín PEDROSA ${ }^{4}$, Antonio Javier BORDERÍAS ${ }^{1}$
}

\begin{abstract}
In the studied commercial pea protein isolate (PPI) some physicochemical modifications are induced in the protein structure during its processing. That fact would result into a reduction of proteins techno-functional properties. It has been evidenced by Differential Scanning Calorimetry the protein denaturation what gives as a result poor gelling ability. Microbial transglutaminase (MTGase) was added at different concentrations to improve the gelation process at two different settings/thermal treatments to make suitable texture PPI gels as a base for various meat and/or seafood analogues. SDS-PAGE analysis indicated that MTGase activity was focused on the polymerization of vicilins and legumins resulting in the promotion of new intermolecular protein complexes (increase in $\beta$-sheet aggregates). Rheological data showed that at 23\% PPI with 5 and $7 \mathrm{U} / \mathrm{g}$ protein of MTGase the gel strength increased in terms of breaking force and complex modulus. It also improved the conformational stability and flexibility of their gel networks. The results suggest that appropriate gels with 23\% PPI could be obtained adding 5 U/g MTGase able to be used as meat and/or seafood analogues.
\end{abstract}

Keywords: pea protein isolate; rheological properties; heat induced-gelation; enzymatic crosslinking.

Practical Application: Commercial pea protein isolate can be used to make meat or seafood analogues with different physicochemical and rheological properties. To improve the techno-functional properties, the addition of some gelation coadjuvant such as microbial transglutaminase would be very convenient in combination with different concentration of pea protein isolate.

\section{Introduction}

There is increasing consumer demand for convenient and healthy foodstuffs of vegetable origin. Vegetable proteins have high potential for use in the food industry in the formulation of new meat and seafood analogue products as a more accessible and sustainable alternative to animal proteins.

Flour and protein isolate from pulses have proven to have good techno-functional properties (Tang \& Ma, 2009) which could be affected during the obtaining process.

Dried peas and other pulses are good sources of proteins, fibre, starch, vitamins and minerals. They are also rich in phytochemicals (galactosides, saponins, phytates, phenols, lectins or protease inhibitors), which have generally been associated with several health benefits (Muzquiz et al., 2012).

There are two main ways of obtaining pea protein isolate (PPI) by salt solubilization of the proteins, and by alkaline solubilization of proteins and further isoelectric precipitation. This last procedure is followed by the industry to obtain high yield of PPIs. However, this procedure induces some protein denaturation mainly unfolding reducing protein functionality (Shand et al., 2007).
It is known that protein-protein interactions occur after heating-induced denaturation of gels (Gerrard, 2002) and that pea protein gelation depends on several factors such as ionic strength and $\mathrm{pH}$. In this connection, it has been reported that the optimal $\mathrm{pH}$ for the formation of strong gels is $\mathrm{pH} 7.1$ and $2.0 \%(\mathrm{w} / \mathrm{w}) \mathrm{NaCl}$ (Sun \& Arntfield, 2010). Moreover, it has been studied that protein concentration also plays an important role in the gel formation; in commercial PPI the optimal concentration has been estimated at around 14.5-19.6\% (Shand et al., 2007; Sun \& Arntfield, 2010).

Microbial transglutaminase (MTGase) is an enzyme that irreversibly catalize covalent cross-linking of proteins by forming isopeptide bonds between glutamine and lysine residues (Nio et al., 1986). MTGase has been used in many kind of products in order to improve protein gelation, for instance in chicken burgers (Uran \& Yilmaz, 2017), pork products (Li et al., 2013), fish (Cando et al., 2016) and yoghurt (García-Gómez et al., 2019). It has also been used in vegetal proteins such as soy and wheat to make tofu, bread, bakery products and pasta (Dube et al., 2007). MTGase has also been used to improve the gelation of native PPI although PPI is considered a poor substrate for MTGase 
(Schäfer et al., 2007, 2011; Shand et al., 2008). However, the initial pea protein denaturation of commercial PPI could make it difficult the protein gelation by the formation of protein polymers linked by inter- and intra-molecular cross-links and the formation of new disulphide bonds between adjacent proteins (Marco et al., 2007). That fact is an important inconvenience when gels used as meat or seafood analogues what to be made. In these gels structural, physicochemical and rheological properties are of paramount importance.

So, the purpose of this paper was to study the gel-forming capacity of a low cost commercial pea protein isolate and the effect of MTGase in different gelation processes.

\section{Materials and methods}

\subsection{Raw material and proximate analysis}

The pea protein isolate (PPI) was provided by the company PEVESA (Sevilla, Spain). The isolate was prepared using alkaline solubilization and isoelectric precipitation techniques from pea (Pisum sativum) flour. Total protein content was analysed with a LECO ${ }^{\circledR}$ CNS-2000 apparatus and with a nitrogen conversion factor of 5.45 (Mosse, 1990). Soluble protein content was determined by the Bradford (1976) method. Moisture, ash and fat contents were determined according to official AOAC procedures (Association of Official Analytical Chemists, 2000, methods 925.09, 923.03 and 920.39, respectively). Carbohydrate content was calculated by difference (total solids minus moisture, protein, fat, and ash). Starch content was determined using a Megazyme kit (Wicklow, Ireland) based on the AOAC method 996.11 (Association of Official Analytical Chemists, 1998) and AACC method 76.13 (American Association of Cereal Chemist, 1976).

\subsection{Least Gelation Concentration of the pea protein isolate}

The Least Gelation Concentration (LGC) was determined by the method of Chau \& Cheung (1998). The $\mathrm{pH}$ value of the PPI was determined according to the official AOAC procedure (Association of Official Analytical Chemists, 2000), since the gelation capacity is affected by $\mathrm{pH}$.

\subsection{Samples preparation}

Samples were prepared using commercial pea protein isolate in different concentrations (17\%,20\% and 23\%). To make the gels, $4.5 \%$ sodium caseinate (Manuel Riesgo, S.A., Madrid, Spain), $2 \% \mathrm{NaCl}$ (w/w of PPI) (Panreac, Química, S.A., Barcelona, Spain) and water up to $100 \%$ were also added to samples containing $17 \%$, $20 \%$ or $23 \%$ PPI (code 17,20 or 23 ). To each sample, MTGase (WM, 99\% Maltodextrine and 1\% enzyme with an activity approx. $100 \mathrm{U} / \mathrm{g}$ of powder; Ajinomoto Co., North America, Inc., USA) was added at $0 \mathrm{U} / \mathrm{g}, 5 \mathrm{U} / \mathrm{g}$ and $7 \mathrm{U} / \mathrm{g}$ of protein (code 0,5 or 7 ). The mixture of the different concentrations of PPI, sodium caseinate (enzyme substrate), $\mathrm{NaCl}$ and water was homogenized at $80^{\circ} \mathrm{C} / 5 \mathrm{~min}$. That mixture was cooled down to $40^{\circ} \mathrm{C}$ prior to the addition of the appropriate amount of enzyme. In all cases, samples were finally homogenized under vacuum for 2 min (Mestra, Iris 2, Bilbao, Spain).
Resulting samples were stuffed into $35 \mathrm{~mm}$ Krehalon casings (Amcor group Flexibles Hispania S.L., Barcelona, Spain) and subjected to two different setting/heating treatments, viz.: Q1 consisting of $40^{\circ} \mathrm{C} / 1$ hour $+5^{\circ} \mathrm{C}$ overnight $+90^{\circ} \mathrm{C} / 30 \mathrm{~min}$, and Q2 consisting of $40{ }^{\circ} \mathrm{C} / 1$ hour $+90^{\circ} \mathrm{C} / 30 \mathrm{~min}+5^{\circ} \mathrm{C} /$ overnight. Samples were kept refrigerated at $5{ }^{\circ} \mathrm{C}$ overnight before analysis (code Q1 or Q2). The concentration of the different ingredients added and the two different setting/heating treatments correspond to common values and treatments used to make gels from myofibrillar proteins, which is the final objective of studying pea protein gelation ability.

\subsection{Differential Scanning Calorimetry (DSC)}

Thermal behavior of the proteins was monitored using a differential scanning calorimeter (DSC Q1000, TA Instruments, New Castle, USA). Analytical samples were not subjected to any heating treatment so as not to induce any additional protein denaturation. The target samples were the ones containing the appropriate PPI concentration (17\%, 20\% and 23\%) dissolved in distilled water, hence these samples are referenced as hydrated samples. Samples were placed in hermetically sealed aluminum pans. The approximate sample weight was around $10 \mathrm{mg}$ as determined by electronic scales (Sartorius ME235S, Goettingen, Germany). The samples were scanned in triplicate at $10^{\circ} \mathrm{C} / \mathrm{min}$ from $5^{\circ} \mathrm{C}$ to $110^{\circ} \mathrm{C}$ under a dry nitrogen purge at $50 \mathrm{~mL} / \mathrm{min}$. Second scans were recorded after cooling $\left(30^{\circ} \mathrm{C} / \mathrm{min}\right)$ down to $5{ }^{\circ} \mathrm{C}$ to check for residual/new effects. Temperature, Tpeak $\left({ }^{\circ} \mathrm{C}\right)$ and enthalpy of transition $\Delta \mathrm{H}(\mathrm{J} / \mathrm{g}$ of protein) were determined for each sample.

\subsection{SDS-PAGE analysis}

All samples were analysed to ascertain the changes occurring in the protein as a consequence of the different treatments (Q1 and Q2). Samples were dissolved in the SDS-UM-solution, consisting of $2 \%$ SDS, $8 \mathrm{M}$ urea, $5 \%$ 2-mercaptoethanol and $20 \mathrm{mM}$ Tris $\mathrm{HCl}$ (pH 7.5) following Konno \& Imamura (2000). The final protein concentration was $20 \mu \mathrm{g}$ per well. The pea protein profile of the different gels was monitored using $13 \%$ polyacrylamide gel electrophoresis in the presence of sodium dodecylsulphate (SDS-PAGE). The ChemiDoc XRS+ system controlled by Image Lab ${ }^{\text {pax }} 5.1$ (Bio Rad, Madrid, Spain) was used for a relative quantification of the band areas corresponding to legumin and vicilin.

\subsection{Fourier Transform Infrared Spectroscopy (FTIR)}

To determine the changes occurring in the protein secondary structure as a consequence of the different treatments (Q1 and Q2), the corresponding PPI concentrations (17\%, 20\% and 23\%) were measured after freeze-drying. Spectra between 4000 and $650 \mathrm{~cm}^{-1}$ were recorded using a Perkin-Elmer Spectrum 400 Infrared Spectrometer (Perkin-Elmer Inc., Waltham, MA, USA) equipped with an ATR prism crystal accessory. The spectral resolution was $4 \mathrm{~cm}^{-1}$. Measurements were performed at room temperature using approximately $1 \mathrm{mg}$ of each gel sample, which was placed on the surface of the ATR crystal and pressed with a flat-tip plunger until suitable spectral peaks were obtained. 
All experiments were carried out in triplicate in order to ascertain how protein structure influenced the physicochemical properties of the gels due to the changes in their protein secondary structures. To increase spectral resolution, a second-derivative spectrum was determined in which the minimum sharp signal marks the maximum intensity region in the original spectrum. Moreover, Fourier self-deconvolution (FSD) spectra were used to analyse the Amide I band components, so as to enhance the spectral resolution and gain insight into changes related to the secondary structure (Kong \& Yu, 2007). Background interference was eliminated using the Spectrum software version 6.3.2 (Perkin-Elmer Inc.).

\subsection{Mechanical properties: puncture test}

Puncture test was carried out at room temperature $\left(25^{\circ} \mathrm{C}\right)$ on all samples containing $20 \%$ and $23 \%$ PPI, up to breaking point. The poor texture of the gels containing 17\% PPI made them unsuitable for measurement. Puncturing was performed on PPI gels of fixed size (diameter $35.0 \mathrm{~mm}$; height $30.0 \mathrm{~mm}$ ) using a $5 \mathrm{~mm}$ diameter cylindrical stainless steel plunger attached to a $50 \mathrm{~N}$ cell connected to the crosshead on a TA-XT plus Texture Analyser (Texture Technologies Corp., Scarsdale, NY, USA). Breaking Force (BF) and Breaking Deformation (BD) were determined from force-deformation curves derived at $1.0 \mathrm{~mm} \mathrm{~s}^{-1}$ crosshead speed. The measurements were carried out in triplicate.

\subsection{Oscillatory measurement}

Small amplitude oscillatory shear (SAOS) tests were performed using a RS600 Haake-rheometer Thermo Electron (Karlsruhe, GmbH, Germany) on Q1 and Q2 samples containing 20\% and $23 \%$ PPI. The measurements were carried out using parallel-plate geometry (20 mm diameter and $1 \mathrm{~mm}$ gap). Samples were cut into disk-shaped slices $20 \mathrm{~mm}$ in diameter and $1 \mathrm{~mm}$ thick and they were allowed to rest for $15 \mathrm{~min}$ to ensure thermal and mechanical equilibrium at the time of measurement. Samples were covered with a trap solvent to preserve the moisture content during measurements. The measurement temperature was $20 \pm 0.1^{\circ} \mathrm{C}$ controlled to within $0.1^{\circ} \mathrm{C}$ by a Peltier element. Measurements were carried out in quintuplicate.

Stress sweeps are known to provide an excellent basis for comparing the viscoelastic properties of food gels. To determine the linear viscoelastic (LVE) region, stress sweeps were run at $12.6 \mathrm{rad} / \mathrm{s}$, at $20^{\circ} \mathrm{C}$ with the shear stress $(\sigma)$ of the input signal varying from 50 to $5000 \mathrm{~Pa} ; 500$ points on the continuous mode were obtained in all instances. The critical (maximum) values of shear strain $\left(\gamma_{\max }\right)$, and shear stress $\left(\sigma_{\max }\right)$ at the limit of LVE range were obtained based on Campo-Deaño \& Tovar (2009). Changes in storage modulus $\left(G^{\prime}\right)$, loss modulus $\left(G^{\prime \prime}\right)$ and complex modulus: $G^{*}=\left(G^{2}+G^{\prime \prime}\right)^{0.5}$ were recorded.

\subsection{Statistical analysis}

One-factor ANOVA analysis was carried out with the SPSS $^{\circledR}$ computer programme (SPSS Inc., Chicago, IL, USA) and average differences were evaluated by the Tukey test using a 95\% confidence interval. Viscoelastic data are presented as mean values of at least five independent batches and were tested with expanded uncertainty limits (EUL) as the maximum and minimum deviation from the respective mean value. Trends were considered significant when means of compared sets differed at $\mathrm{p}<0.05$ (Student's t-test).

\section{Results and discussion}

\subsection{Chemical composition and functional properties of pea protein isolate}

Noteworthy that the amount of protein and carbohydrates, as well as other compounds (such as fat) present in the PPI can affect the techno-functional properties of the isolate, mainly in heat-induced gelation where the presence of starch increases gel firmness (Barac et al., 2015; Pelgrom et al., 2015). The total and soluble protein and ash content of the commercial PPI was $(68.85 \pm 0.09) \%(5.45 \times \mathrm{N}),(29.40 \pm 0.23) \%$ and $(3.50 \pm 0.03) \%$ respectively. The proportion of carbohydrates was $(26.60 \pm 0.11) \%$, of which $(0.31 \pm 0.01) \%$ was starch. These values were similar to or slightly higher than those reported by other authors for commercial pea isolates (Shand et al., 2007; Rubio et al., 2014; Pelgrom et al., 2015). However, the studied PPI had low fat content $(0.5 \%)$, especially in comparison to other commercial pea isolates (3-11.7\%) (Shand et al., 2007; Barac et al., 2015); these differences could be due to lipid-protein binding during protein extraction, causing lipid concentration in the pea isolates (Shand et al., 2007).

The suspension of the PPI powder in water studied in this paper registered a $\mathrm{pH}$ of $6.40 \pm 0.01$. This value was similar to that reported by other authors for PPIs (Adebiyi \& Aluko, 2011; Karaca et al., 2011). These authors reported that PPIs exhibit better gelation capacity at $\mathrm{pH}$ values close to neutral as it is in this case.

The minimum PPI concentration needed for the formation of a gel was $(17.0 \pm 0.1) \%$. This value was similar (16-19.1\%) or higher $(5.5-14.5 \%)$ to that reported by some authors for commercial PPIs (O'Kane et al., 2005; Shand et al., 2007; Sun \& Arntfield, 2010; Adebiyi \& Aluko 2011). The gelling capacity is mainly related to the type and amount of protein in the PPI, although variations in gelling properties have also been associated to the presence of other non-protein constituents such as lipids and carbohydrates (Adebiyi \& Aluko, 2011). The utilization of PPI to develop gels with texture properties similar to meat or seafood analogues depends on the gelation capacity as well as the gel firmness and elasticity (Singh, 2001). However, with the PPI used in this study, the texture of the gels with 17\% PPI lacked sufficient firmness and flexibility to mimic the properties of meat or seafood analogues.

\subsection{Differential Scanning Calorimetry (DSC)}

Transition temperature $(\mathrm{T} d)$ and enthalpy $(\Delta H)$ were determined for all hydrated samples (17\%-20\%-23\%). These results refer only to samples without MTGase since, as previously reported, the treatment with or without MTGase displayed similar thermal curves in PPI samples given that the cross-linking catalysed by MTGase did not significantly alter the thermal stability and protein conformation (Shand et al., 2008). 
PPIs commonly exhibit two different endothermic peaks corresponding to non-globulin fraction components $\left(\mathrm{Td}=67-69^{\circ} \mathrm{C}\right)$ such as crude fibre or/and starch, and globulin fractions $\left(\mathrm{Td}=85-86^{\circ} \mathrm{C}\right)$. Compositional analysis of the PPI indicated a low proportion of starch $(0.31 \%)$, which showed no endothermic peak in the non-globulin fraction area of the thermographs $\left(67-69^{\circ} \mathrm{C}\right)$ (Shand et al., 2007). Moreover, a very low endothermic peak in the globulin range was detected $\left(85.68 \pm 10.25{ }^{\circ} \mathrm{C}, 0.010 \pm 0.001 \mathrm{~J} / g\right.$ protein $)$, indicating PPI denaturation in the analysed samples (Munialo et al., 2014). Protein denaturation could be related to commercial extraction procedures, which include isoelectric precipitation; this is an aggressive method for proteins (Rahaman et al., 2015). In fact, protein isolates prepared at a commercial scale tend to undergo greater denaturation due to harsher drying conditions (spray drying) (Stone et al., 2015) and to greater protein-protein interaction and reduction of hydration at isoelectric point (Cheftel et al., 1985).

\subsection{SDS-PAGE analysis}

Pea proteins are mainly composed of 50-60\% globulins and 15-25\% albumins; globulins are salt-soluble proteins and are composed of two major groups, legumin-type (L $\alpha$ and $\mathrm{L} \beta$ with 40 and $20 \mathrm{kDa}$ ) and vicilin-type $(73,50,33$ and $26 \mathrm{kDa})$. The albumin fraction is composed of lipoxygenase ( $95 \mathrm{kDa})$, albumin PA2 $(26 \mathrm{kDa})$ and others (Owusu-Ansah \& McCurdy, 1991).

Protein profiles of the different samples made with $17 \%, 20 \%$ and 23\% PPI are shown in Figure 1. According to that, regardless of the PPI concentration, the most prominent bands were legumin $\alpha$, legumin $\beta$ and vicilin, as well as some bands corresponding to aggregates that did not enter the gels. These bands at the top of the gel were present in all samples, and are related to proteins denatured and aggregated as a consequence of the isolation process, as noted in the DSC analysis. Non-globulin fractions were not clearly identified in the SDS-PAGE gels, meaning that this particular PPI consists mainly of a globulin fraction.

In all samples, differences in electrophoretic profile were observed between different types of setting (Q1 and Q2) in relation to added MTGase. Any heating process induces protein aggregation (Gerrard, 2002) and that causes an increase in the band intensity at the top of the electrophoresis gel corresponding to protein polymers. As a consequence, several protein bands of lower molecular weight disappear. Similar results were reported by Marco et al. (2007), who also associated this increase in protein bands at the top of the gels treated with MTGase with their ability to form intermolecular cross-links. Then again, in Q1 and Q2 gels, regardless of the protein concentration (Figure 1a, 1b and 1c) the bands most affected by MTGase activity were vicilins $(75 \mathrm{kDa}, 50 \mathrm{kDa})$ and $\mathrm{La}(40 \mathrm{kDa})$, which decreased in the band intensity range around $70.67 \pm 15.73 \%$ and $68.29 \pm 16.51 \%$ respectively (regardless of the MTGase concentration used). However, proteins of lower molecular weight were not clearly affected by MTGase cross-linking. As previously reported, MTGase cross-linking is related to the compactness of the protein structure, particularly in legumins and the access to glutamine and lysine reactive residues of these proteins (Djoullah et al., 2015). Despite the relatively high concentration of glutamine residues in pea proteins, legumins are a poor substrate for MTGase due to their compact globular a) $17 \% \mathrm{PPI}$

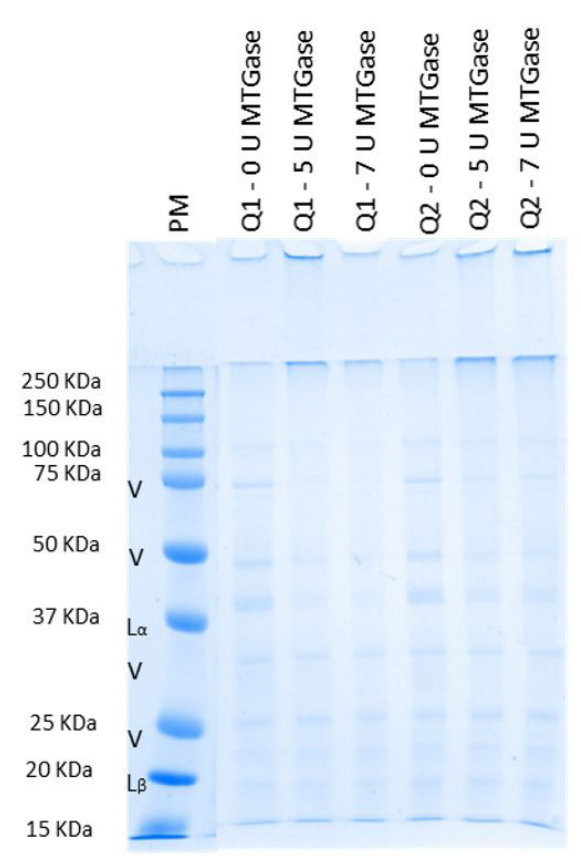

b) $20 \% \mathrm{PPI}$

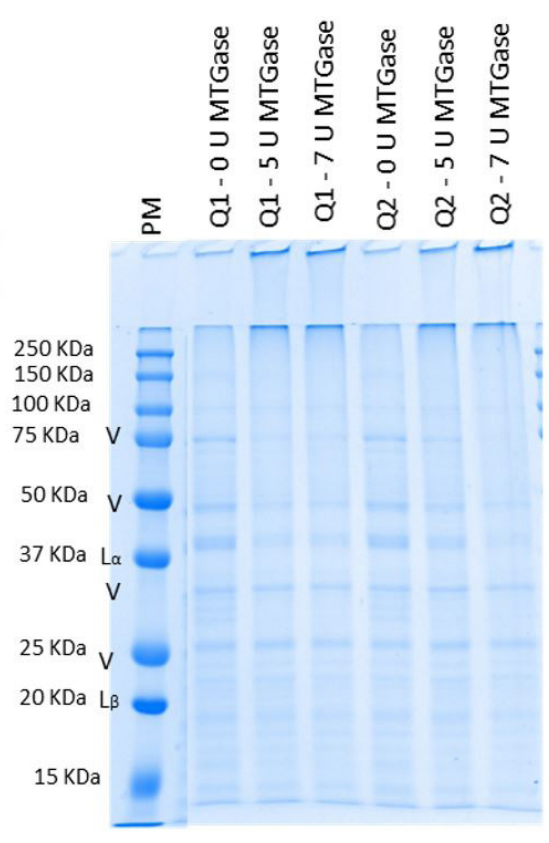

\section{c) $23 \% \mathrm{PPI}$}

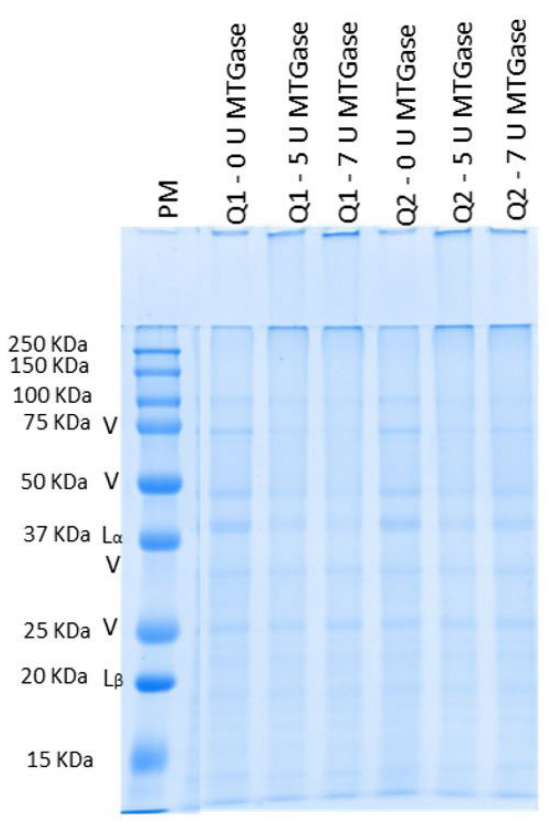

Figure 1. SDS-PAGE profile of gels containing 17\%, 20\% and 23\% Pea Protein Isolate. Q1: Type of treatments defined in the manuscript; Q1: 40 ${ }^{\circ} \mathrm{C} /$ hour $+5{ }^{\circ} \mathrm{C} /$ overnight $+90^{\circ} \mathrm{C} / 30 \mathrm{~min}$; PM: Must be changed by "Marker"; "V": Vicilins; "La": Legumin alpha. 
structure (Dube et al., 2007). Thus, some vicilins ( 55 and $35 \mathrm{kDa}$ ) were partially affected by MTGase while legumin basic subunits $(\mathrm{L} \beta, 20 \mathrm{kDa})$ and vicilins of less than $24 \mathrm{kDa}$ remained mostly intact. The reason for these differences could be the location of the reactive residues, whether they are on the protein surface or are part of the inner hydrophobic core (Djoullah et al., 2015). There is also the fact that only a-polypeptides can be polymerized in the native globular conformation (Dube et al., 2007).

\subsection{Fourier Transform Infrared Spectroscopy (FTIR)}

The Amide I region (1700-1600 $\left.\mathrm{cm}^{-1}\right)$ was selected as the spectral region most sensitive to these changes (Figure 2). The Amide I band $\left(1700-1600 \mathrm{~cm}^{-1}\right)$ is the most relevant for the analysis of protein secondary structures because of its sensitivity to hydrogen bonding, and the geometry of the protein backbone (Barth, 2007). Moreover, this correlates closely with each secondary structural element of the proteins such as $\alpha$-helix $\left(1650-1660 \mathrm{~cm}^{-1}\right)$,

a)
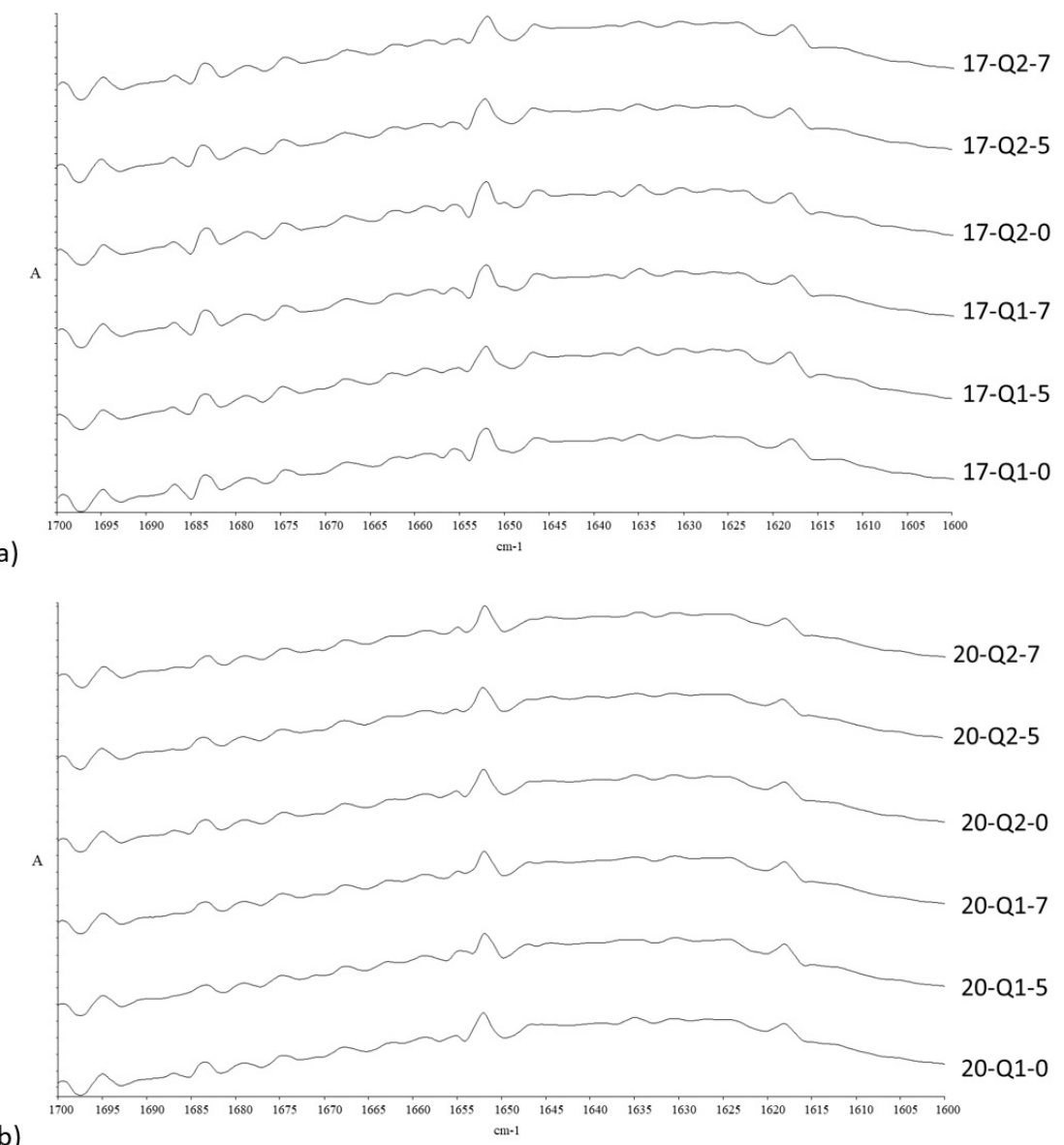

b)

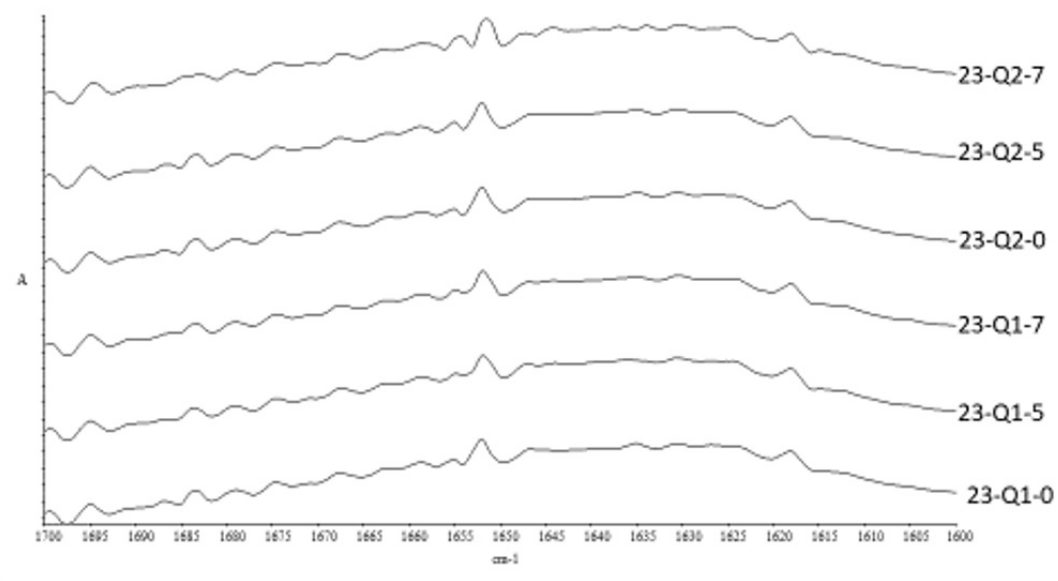

Figure 2. FTIR spectra of gels containing $17 \%, 20 \%$ and $23 \%$ Pea Protein Isolate. Q1: $40{ }^{\circ} \mathrm{C} / 1$ hour $+5{ }^{\circ} \mathrm{C} /$ overnight $+90{ }^{\circ} \mathrm{C} / 30$ min; Q2: $40{ }^{\circ} \mathrm{C} / 1$ hour $+90{ }^{\circ} \mathrm{C} / 30 \mathrm{~min}+5{ }^{\circ} \mathrm{C} /$ overnight. 
$\beta$-bands $\left(1660-1690 \mathrm{~cm}^{-1}, 1630-1638 \mathrm{~cm}^{-1}, 1620-1630 \mathrm{~cm}^{-1}\right)$, intermolecular $\beta$-sheet aggregates $\left(1610-1620 \mathrm{~cm}^{-1}\right)$ and random coils (1640-1648 $\left.\mathrm{cm}^{-1}\right)$, as indicated by Carbonaro et al. (2012). We should also note that the Amide I band in food samples generally appears much broader than the same band detected in purified proteins.

Table 1 shows the distribution of the secondary structure of the gels with different protein concentrations (both settings Q1 and Q2), these values come from the interpretation of the Figure 2 as indicated in 2.5 section. Notice that there were no differences in $\alpha$-helix and random coils with respect to protein or MTGase concentrations. FTIR analysis (Table 1) indicated that the secondary structure in the PPI proteins of the gels was dominated by stable structures such as $\beta$-bands and intermolecular $\beta$-sheet aggregates, which are related to intermolecular protein complexes (Barth, 2007; Carbonaro et al., 2012). $\beta$-sheet aggregates tended to increase in samples with $5 \mathrm{U} / \mathrm{g}$ and $7 \mathrm{U} / \mathrm{g}$ added as compared to the samples without MTGase. MTGase has been widely used to catalyse cross-linking of food proteins and modify their functional properties (Kuraishi et al., 1998; Motoki \& Seguro, 1998). The present results suggest that MTGase can react readily with glutamines and lysine residues of proteins, promoting new covalent bonds resulting in the formation of the new protein complexes. These complexes could contribute to the formation of $\beta$-sheet aggregates. No differences were observed in protein secondary structure as affected by PPI concentration $(17 \%, 20 \%$ or $23 \%)$ in Q1 and Q2 gels (Table 1$)$.

\subsection{Mechanical properties}

Samples containing 17\% PPI were not included in the analysis due to their poor texture for purposes of meat or seafood analogues. As shown in Figure 3, BF and BD were greater in gels containing 23\% PPI regardless of the MTGase concentration, which is normal considering the higher protein concentration and the ability of these proteins to become aggregated by forming electrostatic and covalent bonds when heated (Gerrard, 2002).

Differences in BF were observed between Q1 and Q2 gels with the same level of MTGase. This is related to the ability of MTGase to form inter- or intra-molecular cross-links, the time the enzyme is in contact with its substrate (Kuraishi et al., 1998), and also to the availability of protein substrate, which could result in differences between samples (Mizuno et al., 2000). More specifically, BF values were higher in Q1 than in Q2 (irrespective of protein concentration) when MTGase was added. Then, this suggests that setting at $5{ }^{\circ} \mathrm{C} /$ overnight enhanced the formation of covalent bonds such as $\varepsilon$-( $\gamma$-glutamyl) lysine due to MTGase, resulting in firmer gel networks (Ando et al., 1989).

The effect of MTGase on $\mathrm{BF}$ as relating to PPI concentration was different in Q1 and Q2. In samples with 20\% PPI, BF significantly increased with MTGase addition only from $0-5 \mathrm{U} / \mathrm{g}$ protein in Q1; however, in Q2 there were no changes in BF with increasing MTGase content (Figure 3a). On the other hand, in samples with $23 \%$ PPI, BF of Q1 gels increased significantly with progressive addition of MTGase (Figure 3a), but in Q2 the increase was only significant with 0-5 U/g protein. In all these cases, the increase in $\mathrm{BF}$ produced by MTGase addition is consistent with the greater intermolecular associations observed in larger aggregates in the electrophoresis profiles (Figure 1a to 1c).

$B D$ values in Q1 and Q2 samples with 20\% PPI were constant irrespective of MTGase concentration. This could be related to the low sulfhydryl content and hence to the relatively small number and possibilities of heating-induced S-/SS exchange (O'Kane et al., 2005; Mession et al., 2013). In samples with 23\% PPI, BD values were significantly lower at the highest MTGase concentration both in Q1 and Q2 samples (Figure 3b). This may be a consequence of greater formation of inter- or intra-molecular cross-links (covalent bonds) produced by MTGase when the substrate protein increased (Mizuno et al., 2000; Uresti et al., 2004; Shand et al., 2008) resulting in a brittle gel structure. This brittleness of the structure is also consistent with the larger aggregates observed in the electrophoresis profiles (Figure 1a to 1c).

\subsection{Linear viscoelastic range}

To show the influence of heating method and MTGase content on the gel strength of samples, the comparative values of complex modulus $\left(G^{*}\right)$ in the LVER have been included, since $G^{*}$ provides a measure of the overall resistance to the elastic and viscous deformation (Mezger, 2006).
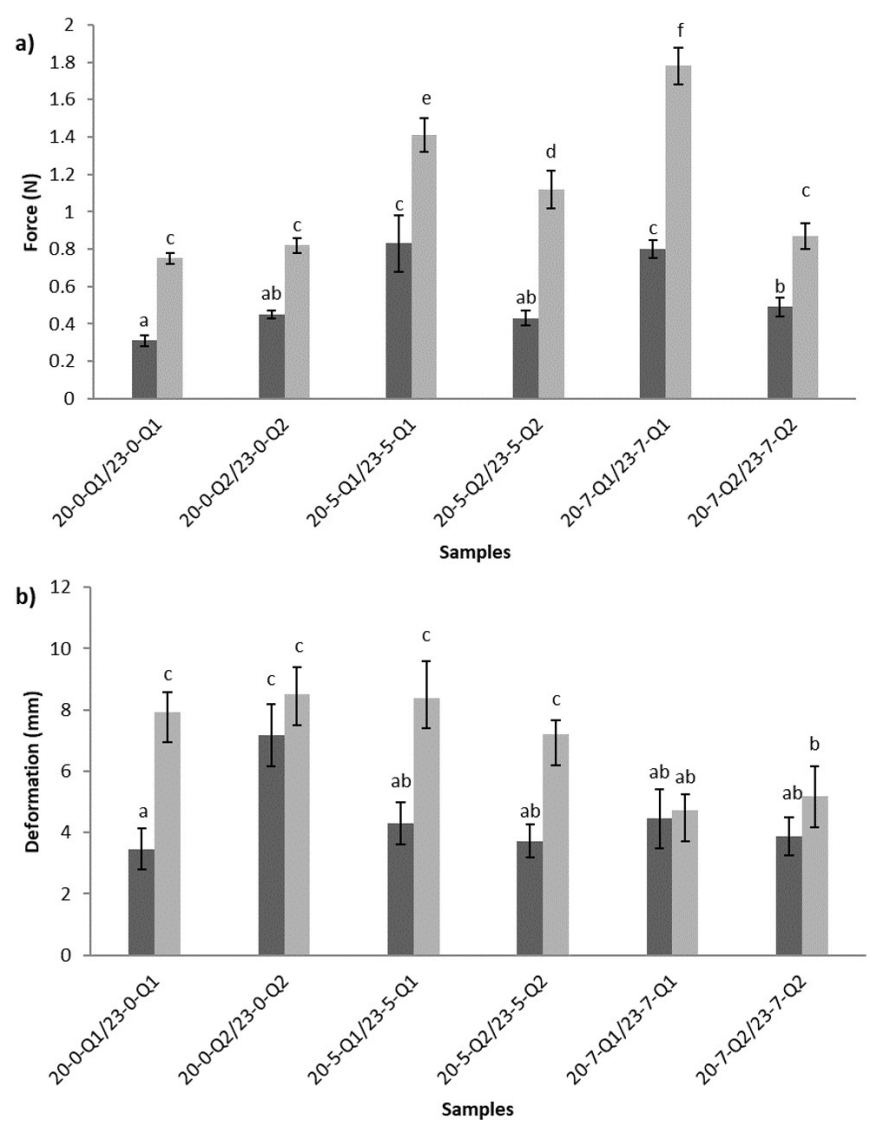

Figure 3. Breaking force (a) and Breaking deformation (b) of gels containing 20\% and 23\% Pea Protein Isolate. Different letters mean significant differences $(\mathrm{p}<0.05)$ in Breaking force and Breaking deformation among all samples. Q1: $40{ }^{\circ} \mathrm{C} / 1$ hour $+5{ }^{\circ} \mathrm{C} /$ overnight $+90{ }^{\circ} \mathrm{C} / 30 \mathrm{~min}$; Q2: $40{ }^{\circ} \mathrm{C} / 1$ hour $+90{ }^{\circ} \mathrm{C} / 30 \mathrm{~min}+5{ }^{\circ} \mathrm{C} /$ overnight. 


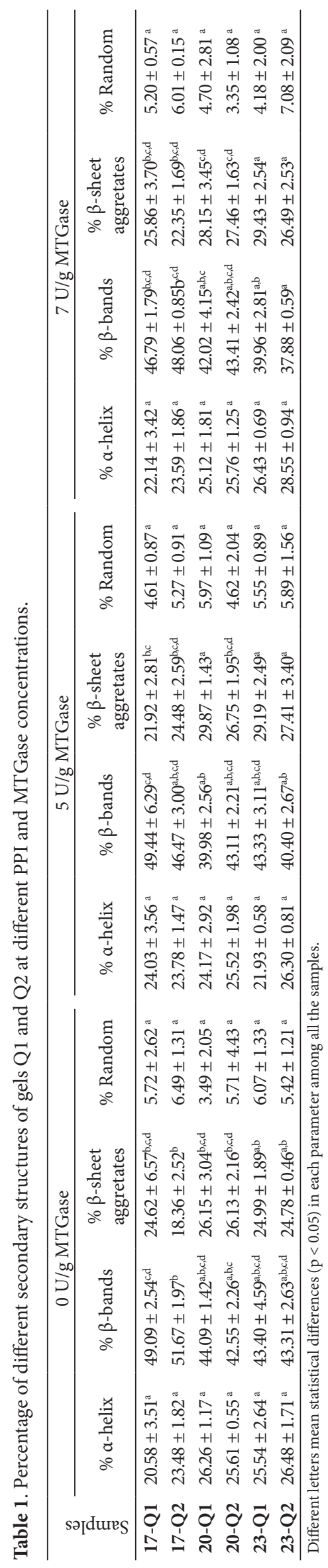



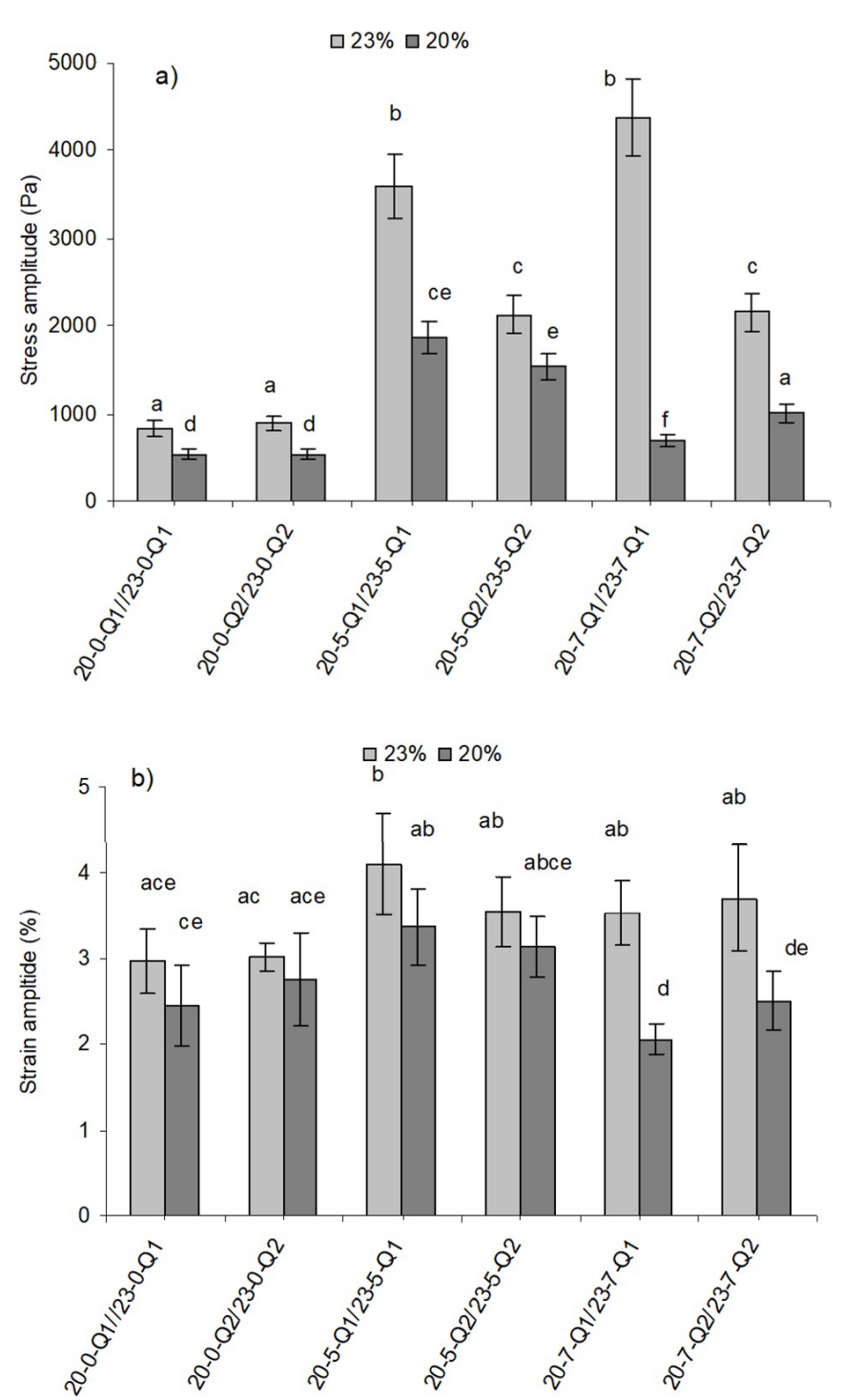

Figure 4. Stress amplitude (a) and Strain amplitude (b) of gels containing $20 \%$ and $23 \%$ PPI. Different letters mean significant differences $(\mathrm{p}<0.05)$ among all samples. Q1: $40{ }^{\circ} \mathrm{C} / 1$ hour $+5{ }^{\circ} \mathrm{C} /$ overnight $+90{ }^{\circ} \mathrm{C} / 30 \mathrm{~min}$; Q2: $40{ }^{\circ} \mathrm{C} / 1$ hour $+90{ }^{\circ} \mathrm{C} / 30 \mathrm{~min}+5{ }^{\circ} \mathrm{C} /$ overnight.

In general, gels with 23\% PPI exhibited higher values of $\sigma_{\max }$ and $\gamma_{\max }$, irrespective of MTGase content in Q1 and Q2 (Figure $4 \mathrm{a}, \mathrm{b}$ ) than in gels with $20 \%$ PPI. So, at 23\% PPI, the level of connectivity was enhanced and the solid matrix exhibited a more strain-stable structure with a wider interval of $\gamma_{\max }$. These data are in line with trends observed in higher BD values of $23 \%$ vs 20\% PPI gels from puncture tests (Figure $3 \mathrm{~b}$ ).

In samples with the same heating (Q1 or Q2), MTGase was associated with different trends in the viscoelastic parameters depending on the PPI concentration. In the case of Q1 gels with $20 \%$ PPI, $\sigma_{\max }$ increased significantly with increasing MTGase from $0-5 \mathrm{U} / \mathrm{g}$ protein, as $\operatorname{did} G^{\star}$, indicating a structural improvement with $5 \mathrm{U} / \mathrm{g}$ of MTGase. However, from 5-7 U/g, $\sigma_{\max }$ (Figure $4 \mathrm{a}$ ) and $G^{*}$ decreased significantly (Figure 5). This means that at $20 \%$ PPI with the highest enzyme concentration (7 U/g) there was not enough substrate for the enzymatic

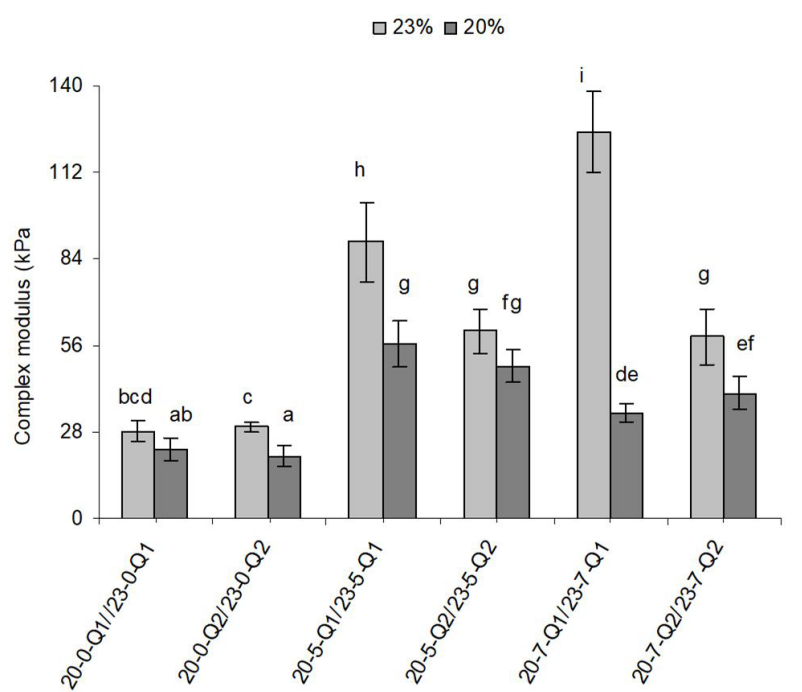

Figure 5. Complex modulus of gels containing 20\% and 23\% Pea Protein Isolate. Different letters mean significant differences $(\mathrm{p}<0.05)$ among all samples. Q1: $40^{\circ} \mathrm{C} / 1$ hour $+5^{\circ} \mathrm{C} /$ overnight $+90^{\circ} \mathrm{C} / 30 \mathrm{~min}$; Q2: $40{ }^{\circ} \mathrm{C} /$ h hour $+90{ }^{\circ} \mathrm{C} / 30 \mathrm{~min}+5^{\circ} \mathrm{C} /$ overnight.

activity; thus, 20-7-Q1 registered a lower shear strain than either 20-5-Q1 or 20-0-Q1 (Figure 4b). Moreover, the values of $\sigma_{\max }$ and $G^{*}$ were significantly lower in 20-7-Q1 than in 20-5-Q1. Moreover, sample 20-7-Q1 exhibited a more brittle network (low $\left.\gamma_{\max }\right)$ than $20-5-\mathrm{Q} 1$, or even than sample without MTGase (20-0-Q1). In the case of Q2 for 20\% PPI gels with and without MTGase, the trends of the viscoelastic parameters were qualitatively similar to Q1 samples (Figures 4 and 5).

In the case of Q1 gels with 23\% PPI, $\sigma_{\max }$ increased with increasing MTGase from 0-5-7 U/g protein (Figure $4 \mathrm{a}$ ), and gel strength $\left(G^{*}\right)$ increased significantly from $0-5$ and 5-7 U/g (Figure 5). These results indicate structural reinforcement produced by heating in a covalent cross-linked network induced by MTGase. These data are consistent with FTIR results based on the increase in the intermolecular complexes $(\beta$-sheet aggregates) in 23-7-Q1 and 23-5-Q1 vs 23-0-Q1. However $\gamma_{\max }$ significantly increased in the $0-5 \mathrm{U} / g$ protein range, while with $7 \mathrm{U} / \mathrm{g}$ MTGase, $\gamma_{\max }$ was the same in 23-7-Q1 and 23-5-Q1. In the case of Q2 gels, the increase in $\sigma_{\max }$ and $G^{\star}$ was only significant from 0-5 U/g MTGase, the same as the trends of BF (puncture tests, Figure $3 \mathrm{a}$ ) in the same range for the corresponding samples (23-7-Q2 and 23-5-Q2 vs 23-0-Q2). As for strand flexibility $\left(\gamma_{\max }\right)$, all values were statistically indistinguishable with increasing MTGase content (Figure 4b). This indicates some structural benefit from an overnight setting at $5 \mathrm{U} / \mathrm{g}$ MTGase and $23 \%$ PPI, as evidenced by greater strand flexibility in the gel network combined with acceptable gel strength. Thus, these structures are adequate components to enhance the intermolecular crosslinks between molecules of different size and shape.

\section{Conclusions}

The data obtained suggest that this commercial PPI, whose main proteins are denatured, shows considerable potential in the food industry for the development of meat or seafood product analogues. 
Suitable gels were gotten with $20 \%$ and $23 \%$ of this PPI with of 5 and $7 \mathrm{U} / g$ protein of MTGase for the Q1 treatment. The enzyme enhanced protein cross-linking, improving the mechanical and rheological properties, especially gel strength (breaking force and complex modulus), structural stability and conformational flexibility. MTGase concentration of $5 \mathrm{U} / \mathrm{g}$ protein seemed to be enough to produce adequate gels; no relevant differences were observed between the two different setting/heating treatments. In conclusion, by gelling this commercial PPI at a concentration of $23 \%$ and adding $5 \mathrm{U} / \mathrm{g}$ MTGase protein with the Q1 setting/heating treatment, it was possible to produce a good gel as a base for making various meat and seafood analogues.

\section{Acknowledgements}

This work was supported by the Spanish Ministry of Economy and Competitiveness (RTA2015-00003-CO2-02).

\section{References}

Adebiyi, A. P., \& Aluko, R. E. (2011). Functional properties of protein fractions obtained from commercial yellow field pea (Pisum sativum L.) seed protein isolate. Food Chemistry, 128(4), 902-908. http:// dx.doi.org/10.1016/j.foodchem.2011.03.116.

American Association of Cereal Chemist - AACC. (1976). Approved methods of the AACC: method 76-11: approved october 1976. St Paul: AACC.

Ando, H., Adachi, M., Umeda, K., Nonaka, M., Uchio, R., Tanaka, H., Motoki, M. (1989). Purification and characteristics of a novel transglutaminase derived from microorganisms. Agricultural and Biological Chemistry, 53(10), 2613-2617. http://dx.doi.org/10.1080 /00021369.1989.10869735.

Association of Official Analytical Chemists - AOAC. (1998). Official methods of analysis (16th ed.). Washington: AOAC International.

Association of Official Analytical Chemists - AOAC. (2000). Official methods of analysis (16th ed.). Washington: AOAC International.

Barac, M., Pešić, M., Stanojevic, S., Kostić, A., \& Cabrilo, S. (2015). Techno-functional properties of pea (Pisum sativum) protein isolates: a review. Acta Periodica Technologica, 46(46), 1-18. http://dx.doi. org/10.2298/APT1546001B.

Barth, A. (2007). Infrared spectroscopy of proteins. Biochimica et Biophysica Acta, 1767(9), 1073-1101. http://dx.doi.org/10.1016/j. bbabio.2007.06.004. PMid:17692815.

Bradford, M. M. (1976). A rapid and sensitive method for the quantitation of microgram quantities of protein utilizing the principle of proteindye binding. Analytical Biochemistry, 72(1-2), 248-254. http://dx.doi. org/10.1016/0003-2697(76)90527-3. PMid:942051.

Campo-Deaño, L., \& Tovar, C. A. (2009). The effect of egg albumen on the viscoelasticity of crab sticks made from Alaska pollock and Pacific whiting surimi. Food Hydrocolloids, 23(7), 1641-1646. http:// dx.doi.org/10.1016/j.foodhyd.2009.03.013.

Cando, D., Borderías, A. J., \& Moreno, H. M. (2016). Combined effect of aminoacids and microbial transglutaminase on gelation of low salt surimi content under high pressure processing. Innovative Food Science \& Emerging Technologies, 36, 10-17. http://dx.doi. org/10.1016/j.ifset.2016.05.010.

Carbonaro, M., Maselli, P., \& Nucara, A. (2012). Relationship between digestibility and secondary structure of raw and thermally treated legume proteins: a fourier transform infrared (FT-IR) spectroscopic study. Amino Acids, 43(2), 911-921. http://dx.doi.org/10.1007/ s00726-011-1151-4. PMid:22102054.

Chau, C. F., \& Cheung, P. C. K. (1998). Functional properties of flours prepared from three Chinese indigenous legume seeds. Food Chemistry, 61(4), 429-433. http://dx.doi.org/10.1016/S0308-8146(97)00091-5.

Cheftel, J. C., Cuq, J. L., \& Lorient, D. (1985). Protéines alimentaires: biochimie, propriétés fonctionnelles, valeur nutritionnelle, modifications chimiques (Technique et Documentation, pp. 45-94). Paris: Lavoisier.

Djoullah, A., Djemaoune, Y., Husson, F., \& Saurel, R. (2015). Nativestate pea albumin and globulin behaviour upon transglutaminase treatment. Process Biochemistry, 50(8), 1284-1292. http://dx.doi. org/10.1016/j.procbio.2015.04.021.

Dube, M., Schäfer, C., Neidhart, S., \& Carle, R. (2007). Texturization and modification of vegetable proteins for food application using microbial transglutaminase. European Food Research and Technology, 225(2), 287-299. http://dx.doi.org/10.1007/s00217-006-0401-2.

García-Gómez, B., Romero-Rodríguez, A., Vázquez-Oderiz, L., MuñozFerreiro, N., \& Vázquez, M. (2019). Sensory quality and consumer acceptance of skim yogurt produced with transglutaminase at pilot plant scale. International Journal of Dairy Technology, 72(3), 388394. http://dx.doi.org/10.111/1471-0307.12595.

Gerrard, J. A. (2002). Protein-protein cross-linking in food: methods, consequences, applications. Trends in Food Science \& Technology, 13(12), 391-399. http://dx.doi.org/10.1016/S0924-2244(02)00257-1.

Karaca, A. C., Low, N., \& Nickerson, M. (2011). Emulsifying properties of chickpea, faba bean, lentil and pea proteins produced by isoelectric precipitation and salt extraction. Food Research International, 44(9), 2742-2750. http://dx.doi.org/10.1016/j.foodres.2011.06.012.

Kong, J., \& Yu, S. (2007). Fourier transform infrared spectroscopic analysis of protein secondary structure. Acta Biochimica et Biophysica Sinica, 39(8), 549-559. http://dx.doi.org/10.1111/j.1745-7270.2007.00320.x. PMid:17687489.

Konno, K., \& Imamura, K. (2000). Identification of the 150 and 70 $\mathrm{KDa}$ fragments generated during the incubation of salted surimi paste of walleye Pollack. Nippon Suisan Gakkaishi, 66(5), 869-875. http://dx.doi.org/10.2331/suisan.66.869.

Kuraishi, C., Sakamoto, J., \& Soeda, T. (1998). Application of transglutaminase for meat processing. Die Fleischwirtschaft, 78(6), 657-658.

Li, C., Xiong, Y. L., \& Chen, J. (2013). Protein oxidation at different salt concentrations affects the cross-linking and gelation of pork myofibrillar protein catalyzed by microbial transglutaminase. Journal of Food Science, 78(6), C823-C831. http://dx.doi.org/10.1111/17503841.12138 .

Marco, C., Pérez, G., Ribotta, P., \& Rosell, C. M. (2007). Effect on microbial transglutaminase on the protein fractions of rice, pea and their blends. Journal of the Science of Food and Agriculture, 87(14), 2576-2582. http://dx.doi.org/10.1002/jsfa.3006. PMid:20836164.

Mession, J. L., Sok, N., Assifaoui, A., \& Saurel, R. (2013). Thermal denaturation of pea globulins (Pisum sativum L.). molecular interactions leading to heat-induced protein aggregation. Journal of Agricultural and Food Chemistry, 61(6), 1196-1204. http://dx.doi. org/10.1021/jf303739n. PMid:23298167.

Mezger, T. (2006). The rheology handbook (Chap. 8). Hannover: Vincentz Network GmbH \& Co. KG. https://doi.org/10.1108/ prt.2009.12938eac.006

Mizuno, A., Mitsuiki, M., \& Motoki, M. (2000). Effect of transglutaminase treatment on the glass transition of soy protein. Journal of Agricultural and Food Chemistry, 48(8), 3286-3291. http://dx.doi.org/10.1021/ jf9911500. PMid:10956103. 
Mosse, J. (1990). Nitrogen-to-protein conversion factor for ten cereals and six legumes or oilseeds: a reappraisal of its definition and determination: variation according to species and to seed protein content. Journal of Agricultural and Food Chemistry, 38(1), 18-24. http://dx.doi.org/10.1021/jf00091a004.

Motoki, M., \& Seguro, K. (1998). Transglutaminase and its use for food processing. Trends in Food Science \& Technology, 9(5), 204-210. http://dx.doi.org/10.1016/S0924-2244(98)00038-7.

Munialo, C. D., Van der Linden, E., \& de Jongh, H. H. J. (2014). The ability to store energy in pea proteins gels set by network dimensions smaller than 50nm. Food Research International, 64, 482-491. http:// dx.doi.org/10.1016/j.foodres.2014.07.038. PMid:30011678.

Muzquiz, M., Varela, A., Burbano, C., Cuadrado, C., Guillamon, E., \& Pedrosa, M. M. (2012). Bioactive compounds in legumes: pronutritive and antinutritive actions. Implications for nutrition and health. Phytochemistry Reviews, 11(2-3), 227-244. http://dx.doi. org/10.1007/s11101-012-9233-9.

Nio, N., Motoki, M., \& Takinami, K. (1986). Gelation mechanism of protein solution by transglutaminase. Agricultural and Biological Chemistry Journal, 50(4), 851-855. http://dx.doi.org/10.1080/000 21369.1986.10867499.

O’Kane, F. E., Vereijken, J. M., Gruppen, H., \& Van Boekel, M. A. J. S. (2005). Gelation behavior of protein isolates extracted from 5 cultivars of Pisum sativum L. Journal of Food Science, 70(2), 132-137. http://dx.doi.org/10.1111/j.1365-2621.2005.tb07073.x.

Owusu-Ansah, Y. J., \& McCurdy, S. M. (1991). Pea proteins: a review of chemistry, technology of production, and utilization. Food Reviews International, 7(1), 103-134. http://dx.doi.org/10.1080/87559129109540903.

Pelgrom, P. J. M., Boom, R. M., \& Schutyser, M. A. I. (2015). Functional analysis of mildly refined fractions from yellow pea. Food Hydrocolloids, 44, 12-22. http://dx.doi.org/10.1016/j.foodhyd.2014.09.001.

Rahaman, T., Vasiljevic, T., \& Ramchandran, L. (2015). Conformational changes of beta-lactoglobulin induced by shear, heat, and $\mathrm{pH}$ : effects on antigenicity. Journal of Dairy Science, 98(7), 4255-4265. http:// dx.doi.org/10.3168/jds.2014-9010. PMid:25912859.

Rubio, L. A., Pérez, A., Ruiz, R., Guzmán, M. Á., Aranda-Olmedo, I., \& Clemente, A. (2014). Characterization of pea (Pisum sativum) seed protein fractions. Journal of the Science of Food and Agriculture, 94(2), 280-287. http://dx.doi.org/10.1002/jsfa.6250. PMid:23744804.
Schäfer, C., Neidhart, S., \& Carle, R. (2011). Application and sensory evaluation of enzymatically texturised vegetable proteins in food models. European Food Research and Technology, 232(6), 1043-1056. http://dx.doi.org/10.1007/s00217-011-1474-0.

Schäfer, C., Zacherl, C., Engel, K.-H., Neidhart, S., \& Carle, R. (2007). Compartive study of gelation and cross-link formation during enzymatic texturization of legumins proteins. Innovative Food Science \& Emerging Technologies, 8(2), 269-278. http://dx.doi.org/10.1016/j. ifset.2007.01.005.

Shand, P. J., Ya, H., Pietrasik, Z., \& Wanasundara, P. K. J. P. D. (2007). Physicochemical and textural properties of heat-induced pea proteins isolate gels. Food Chemistry, 102(4), 1119-1130. http:// dx.doi.org/10.1016/j.foodchem.2006.06.060.

Shand, P. J., Ya, H., Pietrasik, Z., \& Wanasundara, P. K. J. P. D. (2008). Transglutaminase treatment of pea proteins: effects on physicochemical and rheological properties of heat-induced protein gels. Food Chemistry, 107(2), 692-699. http://dx.doi.org/10.1016/j.foodchem.2007.08.095.

Singh, U. (2001). Functional properties of grain legume flours. Journal of Food Science and Technology, 38(3), 191-199.

Stone, A. K., Avarmenko, N. A., Warkentin, T. D., \& Nickerson, M. T. (2015). Functional properties of protein isolates from different pea cultivars. Food Science and Biotechnology, 24(3), 827-833. http:// dx.doi.org/10.1007/s10068-015-0107-y.

Sun, X. D., \& Arntfield, S. D. (2010). Gelation properties of salt-extracted pea protein induced by heat treatment. Food Research International, 43(2), 509-515. http://dx.doi.org/10.1016/j.foodres.2009.09.039.

Tang, C. H., \& Ma, C. Y. (2009). Heat-induced modifications in the functional and structural properties of vicilin-rich protein isolate from kidney (Phaseolus vulgaris L.) bean. Food Chemistry, 115(3), 859-866. http://dx.doi.org/10.1016/j.foodchem.2008.12.104.

Uran, H., \& Yilmaz, I. (2017). A research on determination of quality characteristics of chicken burgers produced with transglutaminase supplementation. Food Science and Technology, 38(1), 19-25. http:// dx.doi.org/10.1590/1678-457x.33816.

Uresti, R. M., Tellez-Luis, S. J., Ramírez, J. A., \& Vázquez, M. (2004). Use of dairy proteins and microbial transglutaminase to obtain low-salt fish products from filleting waste from silver carp (Hypophthalmichthys molitrix). Food Chemistry, 86(2), 257-262. http://dx.doi.org/10.1016/j. foodchem.2003.09.033. 